\title{
Speleological Investigation of the Largest Limestone Massif in Georgia (Caucasus)
}

\author{
Lasha Asanidze', Zaza Lezhava', Nino Chikhradze1,2 \\ ${ }^{1}$ Vakhushti Bagrationi Institute of Geography, Ivane Javakhishvili Tbilisi State University, Tbilisi, Georgia \\ ${ }^{2}$ School of Natural Sciences and Engineering, Ilia State University, Tbilisi, Georgia \\ Email: Lasha.asanidze@tsu.ge
}

How to cite this paper: Asanidze, L., Lezhava, Z. and Chikhradze, N. (2017) Speleological Investigation of the Largest Limestone Massif in Georgia (Caucasus). Open Journal of Geology, 7, 1530-1537. https://doi.org/10.4236/ojg.2017.710102

Received: September 26, 2017

Accepted: October 23, 2017

Published: October 26, 2017

Copyright $\odot 2017$ by authors and Scientific Research Publishing Inc. This work is licensed under the Creative Commons Attribution International License (CC BY 4.0).

http://creativecommons.org/licenses/by/4.0/

\begin{abstract}
Georgia is home to multiple, widespread limestone massifs with well-developed karst areas and their associated landscape features found throughout the country. Due to geological, geomorphological, and speleological characteristics of the limestone massifs in Georgia, there are developments in classical karst processes and landforms, which contain very impressive karst features, such as dolines, caves, calcite depositions and others. For example, in Georgia, the world's deepest caves are found, such as: Krubera-2197 m; Sarma-1830 m; Pantyukhina-1508; Ilyukhina-1275 m; Kuibyshev-1110 m, and others. Of these, Krubera Cave is currently the deepest in the world. The goal of this work is to present speleological investigation of Muradi Cave, which is developed in Racha limestone massif. Muradi Cave is unique as the fact that it contains almost all types and subtypes of speleothems and sediments recorded nowadays in the caves of the Caucasus region, and the mineral aggregates found in Muradi Cave are rare for the caves of the Caucasus region. Unlike many of the hypogene caves in the region, Murdai Cave is formed from a more traditional mechanism of speleogenesis, but the influence of tectonic activity and complex hydrologic regimes led to the development of speleothems and passage morphology less common in the region and likely from hypogenic overprinting. The primary objectives of this study of Muradi Cave included undertaking important investigation in this country, to better understand the speleogenetic processes.
\end{abstract}

\section{Keywords}

Karst, Cave, Limestone Massif, Pool Speleothems, Georgia

\section{Introduction}

Georgia is a classical karst country in the world, where diverse surface and sub- 
surface karst landforms are developed. The limestone massifs (limestone rocks) occupy more than $6 \%$ of the entire territory of Georgia [1] [2], which includes over 1500 known caves [3] [4]. Karst line along the southern slope of the Caucasus mountain range extends 325 in length [5]. Given the tectonic influences, nature of the bedrock structure, and hydrological complexity of the area, the development of different types of karst features, including both hypogenic and epigenic caves, is possible over time [6] [7] [8] [9].

Geographically, the Muradi Cave is developed in Racha limestone massif, which is located in the Oni and Ambrolauri regions (western Georgia), the total area of which exceeds $590 \mathrm{~km}^{2}$ [10]. The highest elevation of the Racha limestone massif is $2402 \mathrm{~m}$ above sea level (a.s.l.), while the estimated thickness of the massif is 1100 - $1300 \mathrm{~m}$ [11] [12]. Within the karst zone of Georgia, the Racha limestone massif has the largest areal extent, but lacks relief compared to others in the country [13].

In this work, we present a new study of Muradi Cave, and the relevant speleogenetic processes, in an effort to improve the understanding of cave formation in the Caucasus region. The Caucasus region may well serve as an example of this and Muradi Cave provides important clues to the possible origin and evolution of karst processes in the area.

\section{Geology and Climatic Aspects of the Study Area}

The Racha limestone massif is a classic geomorphic region throughout the Caucasus in terms of the development of karst processes and landforms. The Bajocian porphyritic suite is the basis of the massif and Cretaceous carbonate rocks also influence the structure of the stratigraphy [14] [15]. Rocks from almost every part of the Early and Late Cretaceous exist in the region (Figure 1).

The massif consists mainly of Upper and Lower Cretaceous and Paleogene limestones, which have an important influence on the origin and development of the surface and underground karst features and on the water table and its fluctuations due to their geologic characteristics [14] [17].

In the area, where Muradi Cave is allocated the Cretaceous massive limestone rocks are especially widely represented. Their capacity in the vertical section (from top to bottom) is about from 50 to 700 meters. For example, on the Nakerala Pass, in the Muradi Cave allocation area Lower Cretaceous limestones thickness is $750 \mathrm{~m}$ (Figure 2).

The prominence of karst processes in the region is considerably high, due to the rapid movement of water along the structural weaknesses in the limestones. The fault dislocations provide locations for cave's inception and groundwater infiltration; there is a rapid infiltration and inflow of surface water and almost no surface flow on the surface of the massif. Some small surface streams are mostly associated with the rainy and snowmelt periods.

In the Racha limestone massif area the mean annual temperature is $11.2^{\circ} \mathrm{C}$; the mean air temperature of the coldest month (January) is $-0.3^{\circ} \mathrm{C}$, while the 


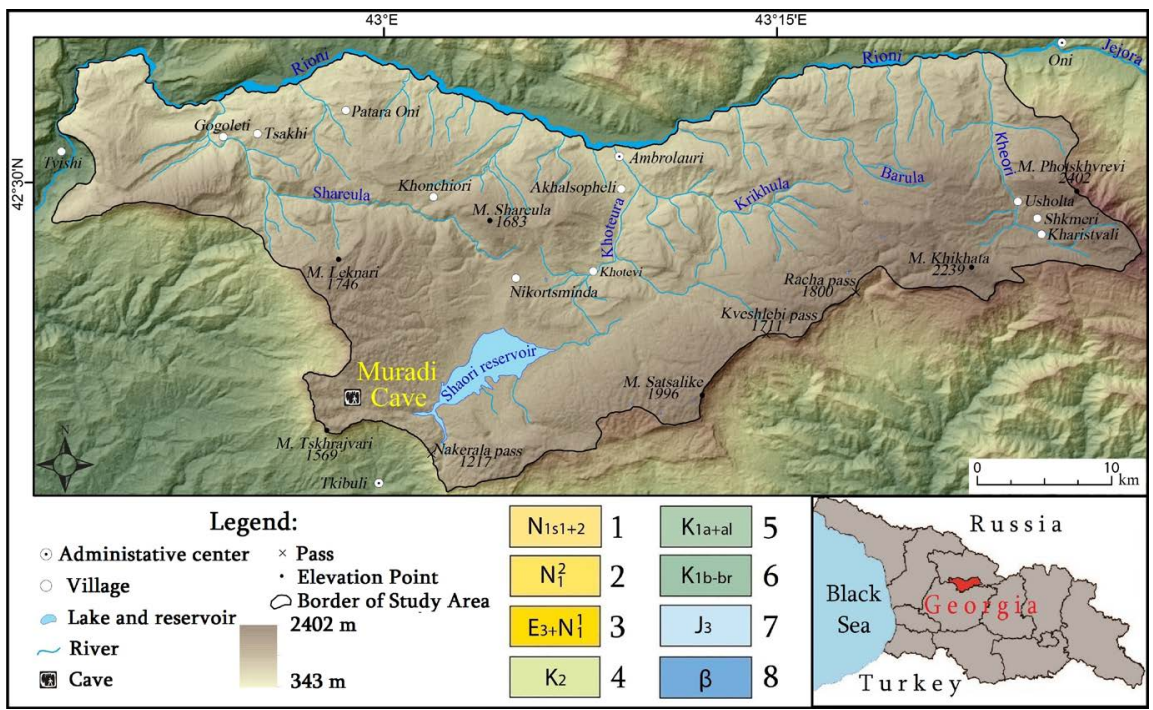

Figure 1. General map of the Racha limestone massif with geological settings [16], Location of Muradi Cave. 1: Lower and Middle Sarmatian; 2: Middle Miocene; 3: Oligocene and Lower Miocene; 4: Upper Cretaceous; 5: Aptian and Albian; 6: Berriasian, Valanginian, Hauterivian and Barremian; 7: Upper Jurassic; 8: Basalts.

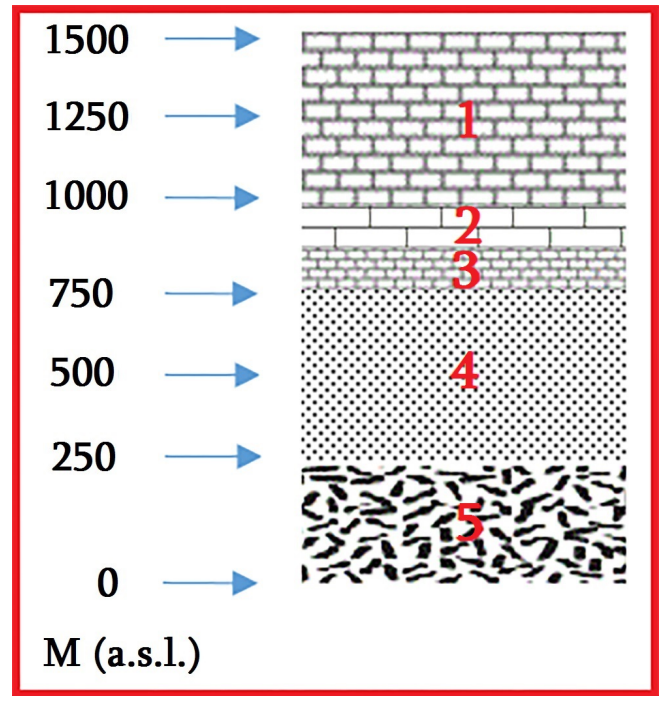

Figure 2. Geological cross section of the Nakerala Range. 1: Barremian stage. 2: Valanginian and Hauterivian stage. 3: Valanginian and Hauterivian stage. 4: Kimmeridgian stage. 5: Bathonian stage.

mean air temperature of the warmest month (August) is $22.1^{\circ} \mathrm{C}$ [18]. Humid air masses blown from the Black Sea $(\sim 120 \mathrm{~km}$ away from the study area) significantly influence the climate of the Racha limestone massif and its karstification due to the amount of precipitation it receives. A major obstacle is the Nakerala Range with its steep slopes, blocking humid air masses arriving from the west. In these areas, updrafts of air masses develop due to the orographic influence and produce a mean annual precipitation total of $2760 \mathrm{~mm}$, according to the Nakerala weather station [18]. 


\section{General Description of the Cave}

Muradi Cave is located in the southwestern part of the Racha limestone massif (See Figure 1). The elevation is $1498 \mathrm{~m}$ a. s. 1. Muradi Cave which contains two levels (upper and lower Level) was discovered 15 years ago, by a local resident, who passed only lower level. Upon discovery, a complex scientific study, supervised by the author, was carried out in the cave by the speleological expedition of the Vakhushti Bagrationi Institute of Geography of Tbilisi State University (TSU).

Lower level of the Muradi Cave is dry and easy to pass through. Here, at some parts limestone rocks are collapsed from the ceiling. Calcite deposits almost do not exist in this section of the cave. The upper level of the cave is significantly interesting, which is connected to the lower level with 10 meters' vertical passage and totally is 489 meters in length. The upper level of the cave is also very interesting, because here exist almost all every types and subtype of calcite deposits, which are documented in the caves of the Caucasus region.

\section{Methods}

During this investigation, we have used basic methods for studying of Muradi Cave to characterize the cave's origin, morphology and mineralogical deposits. The morphological parameters and tectonic directions of Muradi Cave were identified by using the compass-clinometer and laser distance meter. We also used the XRD analysis method for determination of minerals in speleothems. Speleothems mineralogy was analyzed at the Western Kentucky University, KY, USA.

\section{Results and Discussions}

In this study, it was important to make basic survey of the Muradi Cave and collect the information from speleological point of view.

During several expeditions in the Racha limestone massif, the cave was surveyed using a compass-clinometer and laser distance meter. The survey of $\mathrm{Mu}$ radi Cave revealed that it has one main passage with three shorter branches. The 171-meter long horizontal section of the main, lower cave level connects with the upper level through a 10-m vertical passage (Figure 3).

The total length of Muradi Cave is $660 \mathrm{~m}$ with an average passage width of 5 $\mathrm{m}$, average passage height of $8 \mathrm{~m}$ and the floor's mean area of $3500 \mathrm{~m}^{2}$, contributing to a total cave volume of $29,000 \mathrm{~m}^{3}$ (Table 1 ).

A narrow corridor descending westward by $60^{\circ}$ from the entrance is filled with large amount of breakdown. In the right corner of the passage (azimuth $\left.95^{\circ}\right)$, a wide $(5 \mathrm{~m})$ and long $(34 \mathrm{~m})$ tunnel-shaped passage is formed in the Urgonian limestones.

Intense movement of cold air is observed in the terminal section of the cave, evidencing the possible extension of the cave. In the last section of the upper level of the cave 11, 42, 35, and 37 meters' depth karst shafts are represented (See 


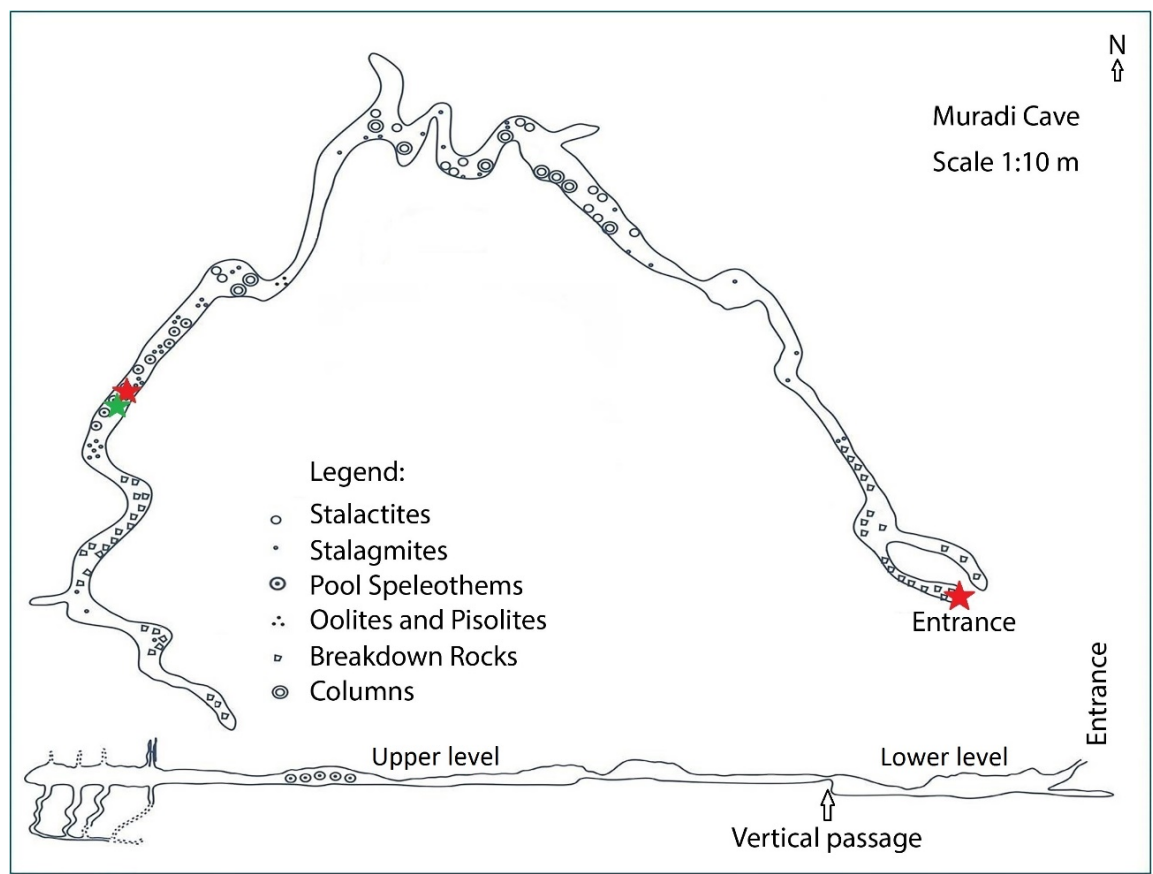

Figure 3. Schematic map and cross-section of Muradi Cave (by Zaza Lezhava and Lasha Asanidze). The red asterisk indicates the places, where the air temperature was measured; green asterisk indicates the place, where the water temperature was measured.

Table 1. Morphometric features of Muradi Cave.

\begin{tabular}{cccc}
\hline \multicolumn{3}{c}{ Morphometric characteristics of Muradi Cave } & Measurement unit \\
\hline 1 & General main length & 600 & $\mathrm{~m}$ \\
2 & Total length & 660 & $\mathrm{~m}$ \\
3 & Average width & 5 & $\mathrm{~m}$ \\
4 & Average height & 8 & $\mathrm{~m}$ \\
5 & Floor's mean area & 3500 & $\mathrm{~m}^{2}$ \\
6 & Total volume & 29,000 & $\mathrm{~m}^{3}$ \\
\hline
\end{tabular}

Figure 3), which are connected to each other through the narrow holes. The cold air mass movement is palpable in the karst shafts section, which, according to the author's opinion, is related to the unknown holes, existed in the cave.

The air temperature was measured in the two sections of the cave, one-at the entrance (slightly above $7^{\circ} \mathrm{C}$ ), and the second-at the end of the cave, near where the speleothems formed in a pool of water. Near this pool, the water temperature are also measured to be $7^{\circ} \mathrm{C}$.

Muradi Cave, which may become a very popular speleo object in this region, is a very rich in calcite speleothems, which contains almost all types and subtypes of speleothems documented nowadays in the caves of the Caucasus region [13] [19]. Beautiful examples of spherical formations (pool speleothems) formed by calcite mineral aggregates give the cave a particular uniqueness and there is no known analog in caves in the whole Caucasus region (Figure 4). 


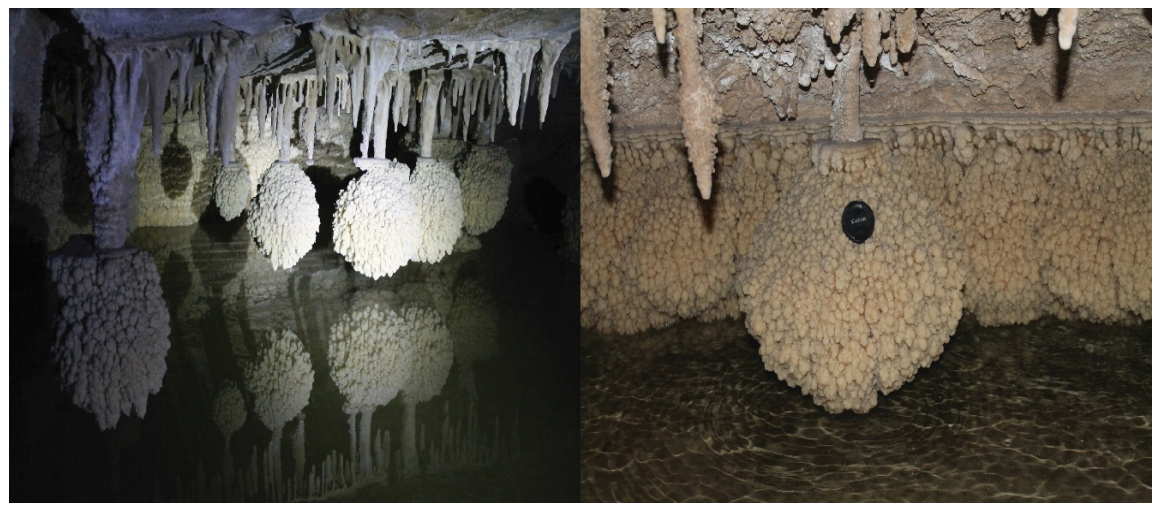

Figure 4. Beautiful examples of pool speleothems in Muradi Cave, which could be formed from water level fluctuations over time (photographs by Lasha Asanidze).

They are mostly subaqueous, lithified calcite balls of different sizes (the smallest is $16 \mathrm{~cm}$ and the largest is $180 \mathrm{~cm}$ in circumference) at one level in a shallow pool in Muradi Cave in the upper level [20]. They seem to have been formed at the same level in the water, perhaps as formations similar to phreatic overgrowth from supersaturated waters existed at higher water levels during times of tectonic change, flooding, or base level shifts and thus indicating a period of higher water table and stability in between tectonic shifts. X-ray diffraction (XRD) analysis confirmed that are $100 \%$ calcite deposits [21].

One of the interesting formations found in Muradi Cave is moonmilk, which is not very common in the caves of the Caucasus region [6] [20] [22]. This formation is mostly found in the wet passages and occupies pools of water. Moonmilk is actively formed under the aggressive influence of condensation waters. The aggressive waters, by dissolving the limestone walls, lead to the formation of the moonmilk [23] [24] [25] and, often, infiltration waters also participate in this process. A study by Geze [26] suggests that microorganisms play an active role in their formation (biochemical weathering) as well, but more work is needed in Muradi Cave to better determine that possibility. However, other authors, such as Shumenko and Olimpiev [27], did not find microorganisms in the moonmilk they studied. It appears, then, that microorganisms are a possible, but not essential, factor in the formation of moonmilk [23].

\section{Conclusion}

An analysis of the Muradi Cave's morphology indicates, it was formed initially under phreatic conditions, and then developed additional levels of vadose canyons and shafts during tectonic uplift, which caused rapid incision and a lowering of the water table in stages over time [28]. During these periods, when stable, epigenic overprinting continued to evolve the cave's passages and connect them, while simultaneously forming speleothems in vadose passages and calcite raft deposits in pools, where the water table remained for long enough periods of time. Unlike many of the hypogene caves in the region, Murdai Cave is formed from a more traditional mechanism of speleogenesis, but the influence of tec- 
tonic activity and complex hydrologic regimes led to the development of speleothems and passage morphology less common in the region and likely from hypogenic overprinting, which is in reverse temporally compared to most cave systems exhibiting both epigenic and hypogenic characteristics.

\section{Acknowledgements}

I would like to thank the Shota Rustaveli National Science Foundation for the research funding within the Doctoral Programs Grant № DO/80/9-280/14.

\section{References}

[1] Asanidze, L., Tsikarishvili, K. and Bolashvili, N. (2013) Cave Tourism Potential in Georgia. The 2nd International Symposium on Kaz Mountains (Mount Ida) and Edremit. Proceedings \& Abstracts. Edremit, 3-5 May 2013, 243-247.

[2] Asanidze, L., Tsikarishvili, K. and Bolashvili, N. (2013) Speleology of Georgia. 16th International Congress of Speleology. Brno, 21-28 July 2013, 1, 29-32.

[3] Asanidze, L., Chikhradze, N., Lezhava, Z., Tsikarishvili, K., Polk, J. and Chartolani, G. (2017) Sedimentological Study of Caves in the Zemo Imereti Plateau, Georgia, Caucasus Region. Open Journal of Geology, 7, 465-477. https://doi.org/10.4236/ojg.2017.74032

[4] Asanidze, L., Tsikarishvili, K., Lezhava, Z., Bolashvili, N., Chikhradze, N. (2015) Discovery and Management of Georgian Caves. Program and Abstracts, 21st National Cave and Karst Management Symposium. Cave City, 19 October 2015.

[5] Lezhava, Z., Tsikarishvili, K., Asanidze, L., Bolashvili, N., Chikhradze, N. and Chartolani, G. (2017) Ecological Investigation of Karst Water in the Central Part of Georgia. Lap Lambert Academic Publishing, Saarbrücken, ISBN: 978-620-2-02210-1.

[6] Tintilozov, Z.K. (1961) Rare Stalactite Shapes and Concretions in the Karstic Caves of Western Georgia. Proceedings of the Vakhushti Bagrationi Institute of Geography, Georgia Academy of Sciences (in Georgian), Tbilisi, 23-25.

[7] Palmer, A.N. (2007) Cave Geology. Dayton, OH. Cave Books. Dayton, Ohio.

[8] Klimchouk, A.B., Samokhin, G.V. and Kasian, Y.M. (2009) The Deepest Cave in the World in the Arabika Massif (Western Caucasus) and Its Hydrogeological and $\mathrm{Pa}$ leogeographic Significance. ICS Proceedings, 15th International Congress of Speleology, Kerrville, 27 July, 2009, 898-905.

[9] Ford, D.C. and Williams, P.W. (2007) Karst Geomorphology and Hidrology. Wiley, Hoboken, 576. https://doi.org/10.1002/9781118684986

[10] Asanidze, L., Avkopashvili, G., Tsikarishvili, K., Lezhava, Z., Chikhradze, N., Avkopashvili, M., Samkharadze, Z. and Chartolani, G. (2017) Geoecological Monitoring of Karst Water in Georgia, Caucasus (Case Study of Racha Limestone Massif). Open Journal of Geology, 7, 822-829. https://doi.org/10.4236/ojg.2017.76056

[11] Kipiani, S. (1974) Karst of Georgia (Attempt of Geomorphological Characterization). V-I, Publishing House Metsniereba, Tbilisi, 13-20. (In Georgian)

[12] Kiknadze, T.Z. (1972) Karst of the Arabika Massif. Metzniereba, Tbilisi, 245. (In Russian)

[13] Lezhava, Z. (2015) The Karst of Zemo Imereti Plateau and Its Surrounding Areas. Publishing House Universali, Tbilisi. (In Georgian)

[14] Rakviashvili, K. (1985) On Karst of the Elevated Dzirula Massif and Shaori Tekton- 
ical Block. Caves of Georgia. The Collection, Tbilisi, Issue 10, 55-62. (In Russian)

[15] Tsikarishvili, K., Lezhava, Z., Asanidze, L., Bolashvili, N., Chikhradze, N. and Chartolani, G. (2015) Geomorphologic Features of Sataplia-Tskaltubo Limestone Massif. Earth Sciences. Sciences Publishing Group.

https://doi.org/10.11648/j.earth.s.2015040501.30

[16] Gudjabidze, G.E. (2003) Geological Map of Georgia, Scale 1:500 000. Georgian State Department of Geology and National Oil Company Saqnavtobi, Tbilisi.

[17] Lezhava, Z., Bolashvili, N., Tsikarishvili, K., Asanidze, L. and Chikhradze, N. (2015) Hydrological and Hydrogeological Characteristics of the Platform Karst (Zemo Imereti Plateau, Georgia). Sinkholes and the Engineering and Environmental Impacts of Karst. Proceedings of the 14th Multidisciplinary Conference, Rochester, 5-9 October 2015, 93-100.

https://www.crossref.org/iPage?doi=10.5038\%2F9780991000951.1058

[18] Kavrishvili, K.V. and Matkava, D.I. (1978) Shaori Karst Depression Landscape Analysis. Caves and Hollows of Georgia, Publishing House Metsniereba, Tbilisi, No. 7, 38-48. (In Russian)

[19] Tintilozov, Z.K. (1976) Karst Caves of Georgia (Morphological Analysis). Tbilisi. (In Russian)

[20] Asanidze, L., Chikhradze, N., Lezhava, Z., Tsikarishvili, K., Polk, S.J., Lominadze, G. and Bolashvili, N. (2017) Complex Speleogenetic Processes and Mineral Deposition in the Caucasus Region of Georgia. Journal of Environmental Biology, 38, 1107-1113. https://doi.org/10.22438/jeb/38/5(SI)/GM-30

[21] Asanidze, L., Lezhava, Z., Tsikarishvili, K., Chikhradze, N. and Polk, J. (2017) Karst Morphological Processes and Evolution of the Limestone Massif of Georgia from Depositional, Sedimentary, and Structural Investigations in Muradi Cave. Proceedings of 17 th International Congress of Speleology, Sydney, 241-247.

[22] Lezhava, Z., Asanidze, L., Tsikarishvili, K., et al. (2016) Cave Murada-the Unique Speleological Object on the Nakerala Range. Science and Technologies. Scientific Reviewed Magazine, 2, 43-50.

[23] Hill, C.A. and Forti, P. (1997) Cave Minerals of the World. 2nd Edition, National Speleological Society, Huntsville.

[24] Merino, A., Gines, J., Tuccimei, P., Soligo, M. and Fornos, J. (2014) Speleothems in Cova des Pas de Vallgornera: Their Distribution and Characteristics within an Extensive Coastal Cave from the Eogenetic Karst of Southern Mallorca (Western Mediterranean). International Journal of Speleology, 43, 125-142. https://doi.org/10.5038/1827-806X.43.2.3

[25] Borsato, A., Frisia, S., Jones, B. and Van der borg, K. (2000) Calcite Moonmilk: Crystal Morphology and Environment of Formation in Caves in the Italian Alps. Journal of Sedimentary Research, 70, 1179-1190.

[26] Geze, B. (1965) La Spéleologie Scietifique. Paris, 190.

[27] Shumenko, S.I. and Olimpiev, I.V. (1997) Rock Milk from Caves in the Crimea and Abhazia. Lithology and Mineral Resources, 12, 240-243. (In Russian)

[28] Lezhava, Z., Tsikarishvili, K., Bolashvili, N., Asanidze, L. and Chikhradze, N. (2015) Preliminary Outcomes of the Eki Mountain Karst-Hydrological and Speleological Study. International Conference, Applied Ecology. Problems and Innovations, Tbilisi, 7-10 May 2015, 89-95. 